\title{
THE IMPORTANCE OF RHYTHMICS IN THE PROCESS OF ELEMENTARY LITERACY ACQUIRING
}

\section{[VYZNAM RYTMIKY PRI NADOBUDANI ELEMENTARNEJ GRAMOTNOSTI]}

\author{
Dana Kollarova
}

\section{doi: 10.18355/PG.2017.6.1.14}

\begin{abstract}
The study solves the problems of didactic methods referring to the process of the 1 st class elementary students' education, concretely the process of acquiring their elementary literacy. Distinctively it depicts and emphasises the importance of activating methods based on rhythm and callisthenics, it respects the knowledge of the neurodidactics. The study introduces the reader to some research results related to the solved problems.
\end{abstract}

\section{Key words}

elementary literacy aquiring, neurodidactics, rhythm, callisthenics, psychomotricity, emotion

\begin{abstract}
Anotácia
Predložená štúdia rieši problematiku didaktických postupov, ktoré sa vzt'ahujú k procesu edukácie žiakov 1. ročníka základnej školy, konkrétne pri nadobúdaní elementárnej gramotnosti. Osobitne popisuje a zdôvodňuje význam uplatňovania aktivizujúcich prvkov založených na rytme a rytmike, pričom rešpektuje poznatky z neurodidaktiky. Štúdia predstaví čitatel’ovi aj niektoré výskumné zistenia, ktoré sa viažu $\mathrm{k}$ riešenej problematike.
\end{abstract}

\section{Kl’účové slová}

nadobúdanie elementárnej gramotnosti, neurodidaktika, rytmus, rytmika, psychomotorika, emócie

\section{Úvod}

Problém, ktorý riešime v našej štúdii, môžeme hl'adat' skôr na periférii školskej edukácie. Ide o problematiku rytmu, resp. rytmiky (výchovy k rytmu), ktorú považujeme pri nadobúdaní elementárnej gramotnosti za opodstatnenú, a to nielen $\mathrm{z}$ toho dôvodu, že diet'a $\mathrm{v}$ predškolskom období prostredníctvom týchto foriem spoznáva, objavuje a učí sa prirodzene jazyk, ale ide o vekuprimerané a prirodzené postupy, ktorými zároveň rozvíjame sociálno-emocionálne, kognitívne aj psychomotorické kvality osobnosti, a to v ich vzájomnej súčinnosti. Treba povedat', že z oblasti rytmu a rytmiky sa vyskytuje ojedinele odborná literatúra a ak, tak prevažne $\mathrm{z}$ hudobnej, hudobno-pohybovej, resp. telesnej výchovy, skôr $\mathrm{z}$ tanca a gymnastiky. V našej viac než dvadsat'ročnej pedagogickej a vedeckovýskumnej činnosti sa venujeme oblasti tvorivej dramatiky, pričom jeden z jej obsahových okruhov, resp. ciel'ov je cítit' rytmus - v slove, v pohybe, v priestore, v hudbe. Vo vyučovacom procese s uplatňovaním metód tvorivej dramatiky ide o také didaktické postupy, ktoré rozvíjajú prirodzenú osobnost' žiaka, učia ho kontaktovat' sa, komunikovat', riešit' konflikty s dôrazom na nonverbálne aj verbálne prostriedky komunikácie (bližšie Kollarova 2002, 2013a). Vychádzajme z predpokladu, že naša 
reč je rytmická. Je to dôsledkom pravidelného striedania prízvučných a neprízvučných segmentov - slabík. Diet’a si okrem počúvania osvojuje reč aj spôsobom založeným na rytmizovaní rozličných útvarov detskej l'udovej slovesnosti, čo pôsobí na neho uvol'ňujúco a prináša mu to zážitok z hry. Do tohto procesu sa túži vracat', pretože mu to prináša pozitívne emócie. Považujeme preto za podnetné a pre diet'a/žiaka prirodzené vo vyučovaní čítania a písania v 1 . základnej školy využívat' rytmické hry so slovom, pohybom, melódiou, s detskými rytmickými nástrojmi (Orffovým inštrumentárom).

Aby sa nám podarilo uvedenú problematiku uchopit' komplexnejšie, budeme sa zaoberat' aj osobitost'ami didaktických postupov pri nadobúdaní elementárnej gramotnosti, pretože si uvedomujeme, že v každom edukačnom zásahu treba brat' do úvahy aj činnost' mozgu žiaka. Z toho dôvodu sa musíme pristavit' aj pri neuropeagogike, resp. neurodidaktike, aby sme predostreli niektoré záležitosti, ako funguje mozog žiaka na vyučovaní. Následne objasníme súvislost' medzi nadobúdaním elementárnej gramotnosti a potrebou rytmu $\mathrm{v}$ tomto edukačnom procese. Ked’že kl'účovou podmienkou takto ladeného edukačného procesu je to, aby na vyučovaní prevládali pozitívne emócie, pozornost' sústredíme aj na potrebu motivácie žiaka. Pripomíname, že proces nadobúdania elementárnej gramotnosti v úvodnom ročníku základnej školy stojí na pilieroch jazyka, motivácie, rytmu a zážitku z hry, ktoré nemôžeme $\mathrm{v}$ žiadnom prípade vnímat' izolovane, znamenajú pre žiaka v tomto období v procese učenia sa pre neho vel'kú hodnotu. V závere štúdie uvedieme niektoré zistenia $\mathrm{z}$ pedagogického skúmania.

\section{Od elementárnej gramotnosti k funkčnej gramotnosti}

$\mathrm{V}$ procese vyučovania materinského jazyka v 1 . ročníku ZŠ, ktorého jadrom je nadobúdanie elementárnej gramotnosti, zohráva vel'kú úlohu kvalita súčinnosti všetkých stránok osobnosti žiaka. Ide o kognitívnu oblast' (vnímanie, pozornost', myslenie, reč, pamät'), percepčno-motorickú (vnímané podnety - fonémy, grafémy preniest' do oromotoriky, grafomotoriky; orientácia na ploche, v priestore, l'avo-pravá orientácia), sociálno-emocionálnu (v novom prostredí s prevažne neznámymi l’ud’mi sa odvážit' komunikačne prejavit', zaujímat' sa o nové poznatky a vediet' prežívat' úspech, aj menší neúspech). Autori, ktorí sa u nás intenzívne venujú jazykovej gramotnosti (Gavora, 2003, 2006, Zapotocna 2003, 2005 2012) zdôrazňujú odvolávajúc sa na zahraničné štúdie, že elementárnou gramotnostou (tiež raná, bázová, bazálna, vynárajúcu sa, konvenčná) chápeme takú úroveň gramotnosti, ktorá v sebe obsahuje zručnost' čítat' a písat' a zároveň tomu aj rozumieme. Môžeme teda povedat', že pri nadobúdaní čítania a písania musia byt' paralelne so všetkými primárnymi (počúvanie, hovorenie) aj sekundárnymi (čitanie, písanie) komponentmi gramotnosti prepojené aj d'alšie dva - komunikácia a myslenie. Toto sa vzt'ahuje aj na výučbu cudzích jazykov, bližšie o tom pojednáva o.i. aj Birova (2016). Každou zvolenou didaktickou metódou žiak musí vnímat' a chápat', že uvedenú skúsenost' vie zmysluplne využit' v komunikačnej, resp. sociálnej situácii. Iba za takýchto podmienok môže žiak pochopit' a ocenit' potrebu gramotnosti. V súlade s uvedenými autormi si dovolíme tvrdit', že nácvik elementárnej gramotnosti je základným ciel’om školy už od prvého ročníka. Len doplníme, že pri výbere metód treba rešpektovat' vlastnú aktivitu diet'at'a/žiaka. Touto vlastnou aktívnou činnost'ou, za ktorou stojí vytvorenie rozmanitých príležitostí žiakom vstúpit' do komunikačnej roviny, vieme stimulovat' a rozvíjat' u nich aj funkčnú gramotnost'. Napokon aj Zapotocna (2012) zdôrazňuje tento fakt, ked' uvádza, že práve osvojenie si komunikačnej kompetencie je podmienkou rozvoja funkčnej gramotnosti. Gramotnost' môžeme teda za funkčnú považovat' $\mathrm{v}$ tom prípade, ak žiak dokáže informácie z počutého, prečítaného alebo prepísaného textu aj funkčne využit' v rôznych reálnych situáciách. 


\subsection{Hláska - slabika - slovo, alebo od slova k hláske}

Posledných desat' rokov sa pedagógovia a výskumníci snažia hl'adat' efektívnejšie cesty k nadobúdaniu gramotnosti, pričom vychádzajú z viacerých teórií. Hladajú možnosti stimulácie, rozvíjania pestovania záujmu o čítanie a písanie, aby čítanie nebolo len technickou a nemennou záležitost'ou, ale aby si žiak uvedomil, že ide o proces tvorivý, v ktorom žiak čítanie pretvára na zmysluplné kontexty. Písanie je zložitejší proces, než čítanie. Spomenieme empirické pozorovania Feirrero (1990, bližšie Viktorova, 2001), ktorá vychádzala z analýzy písomnej produkcie detí a dospela $\mathrm{k}$ identifikácii vývinových etáp nadobúdania gramotnosti, čím podporila princípy Piagetovej teórie. V jej výskumoch bolo významné objavenie štádia, kedy deti objavujú a nadobúdajú vedomosti o dížke slova tým, že si uvedomujú počty slabík. Uvedieme príklad: Môžeme spomenút, že ak sa spýtame žiaka 1. ročníka na začiatku školskej dochádzky, či je dlhšie slovo ruka alebo rukavica, tak nám odpovie ruka. Je to dôkaz toho, že žiak pracuje s predstavou, čo znamená, že rozumie slovu vtedy, ak si urobi obrázok. Nepracuje s predstavou pojmu „slovo“ - nevie si urobit” obrázok, sústredí sa teda na pojmy - dížka, ruka, rukavica.

Rozin, Gleitman (1977, in Gavora, Zapotocna, 2003), považovali slabiky za vhodný úvod k abstraktnému fonemickému konceptu abecedy. Ten sa však odporúčal odložit' na neskôr. Skôr sa odporúčalo začat' celostným štádiom, alebo tzv. párovoasociačným štádiom, prípadne logografickým štádiom (bližšie Gough, Juel, 1991; Goodman, 1986; In Zapotocna, Petrova 2010). Autori vychádzali z predpokladu, že slovo je pre diet'a $z$ hl'adiska kontextu a predstavivosti zrozumitel'nejšie, než taký segment, akým je hláska, alebo slabika. Aj z toho dôvodu sa v súčasnosti opät' niektorí autori Šlabikára (Stefeková, Culkova, Zapotocna) vracajú ku globálnej (celojazykovej, celo-slovnej) metóde českého psychológa V. Prihodu (1930). Treba však povedat', že v súčasnosti pri nadobúdaní elementárnej gramotnosti v našich podmienkach skôr dominuje tradičná analyticko-syntetická metóda, na ktorú boli v minulosti učitelia prioritne pripravovaní a dovolíme si na základe pedagogickej praxe, ako aj výsledkov niektorých uskutočnených výskumov tvrdit', že pravdepodobne nedostatok poznatkov či nedôvera vo vlastné schopnosti im nedovolia sa od nej stále odklonit' (Kollarova, 2008, 2013b).

Treba povedat', že v súčasnosti viacerí autori krajín V4 priznávajú, že klúčovou teóriou k nadobúdaniu gramotnosti sa stáva nedocenená teória Vygotského (1978, In Vygostkij 2004), ktorý zastával názor, že písaná reč je slovne najbohatšou, najpresnejšou a najrozvinutejšou formou reči. S jeho metodikou v súčasnosti začínajú pracovat' uvedené krajiny už v predprimárnom vzdelávaní. Tento vek je dôležitý aj z toho dôvodu, ako napokon uviedla aj Ferreiro (In Zapotocna, 2005), že osvojenie si podpisu vlastného mena možno pokladat' za jeden z najvýznamnejších medzníkov vývinu gramotnosti diet’at’a. A dovolíme si doplnit', že to pre diet’a znamená jeden z najväčších úspechov, čo ho môže zároveň motivovat' $\mathrm{k}$ d'alšiemu objavovaniu zákonitostí písanej reči. Treba povedat', že vo vel'kej miere sa na tejto motivácii podiel'a kvalitne pripravený učitel' so svojou osobnostnou štruktúrou, ktorej súčast'ou by nemala byt' jeho odvaha myslenia. Tá sa premieta $\mathrm{v}$ jeho didaktických postupoch. $\mathrm{Aj}$ preto je potrebné venovat' zvýšenú pozornost' možnostiam prípravy budúcich učitel'ov z oblasti rozvoja sociálneho kontextu (bližšie Duchovicova, Petrova, 2016; Petlak, 2016). O tom, že práve úspech je to, čo žiaka motivuje k d'alšiemu objavovaniu a záujmu učit' sa, sa v našej štúdii ešte zmienime.

\subsection{Motivácia pri nadobúdaní elementárnej gramotnosti}

Ked’že pri nadobúdaní elementárnej gramotnosti ide o žiaka 1. ročníka, pri plnení jej ciel'ov je pre učitel'a dôležité vstupovat' do tohto tvorivého procesu s tým predpokladom, ako to napokon uvádza aj Zapotocna (2012), že diet’a prichádza do školy $\mathrm{s}$ radost'ou a s nadšením $\mathrm{z}$ toho, že objaví procesy čítania a písania. V celom 
štruktúrovaní vyučovania materinského jazyka v 1. ročníku ZŠ vzhl’adom na vekové osobitosti žiaka a na jeho predchádzajúce individuálne komunikačné a sociálne skúsenosti, musí teda učitel' vo vel'kej miere brat' do úvahy emocionálne ladenie vyučovania. Významnú úlohu v tomto období zohráva teda motivácia, a to hlavne v predšlabikárovom a šlabikárovom období. V týchto obdobiach učitel' musí prihliadat' na dôležitost' zmyslového vnímania žiakov (zrakového - identifikovat' obrázky, grafémy; sluchového - vnímat' zvuk fonémy, slabík, slov, viet; hmatového grafomotorika, úchop písacieho materiálu, pravo-l’avá orientácia na ploche, vnímanie tela pri písaní a pod.). Na motiváciu vo vyučovaní upozornili viacerí autori. Helus (2004) dokonca považuje motiváciu, teda podnecovanie žiakov k učeniu, za klúčovú kompetenciu učitel'a. Podobne na to upozornil aj Petlak (2008), ked' píše, že najväčšie rezervy v motivácii vyplývajú z osobnosti pedagóga. Autor rovnako pripomína aj to, že žiakov motivuje úspech, uznanie, výzva $\mathrm{k}$ akcii. $\mathrm{Z}$ toho dôvodu by mala byt' stratégia vyučovacích postupov v 1 . ročníku pri nadobúdaní elementárnej gramotnosti založená na motivácii paralelne s pestrou variabilitou metód $\mathrm{s}$ akcentom na žiakovu aktivitu v cvičeniach, a to na všetky komponenty gramotnosti. Pri úlohách berieme do úvahy vývinové osobitosti žiaka, jeho kognitívny, psychomotorický aj sociálnoemocionálny kontext. Uvedené postupy založené na týchto princípoch nám môžu zabezpečit to, že žiak bude nadobúdat' elementárnu gramotnost' spôsobom, ktorý je pre neho primeraný, zrozumitel'ný, korešponduje s funkčným využívaním jazyka $\mathrm{v}$ dennej realite, a rozmanitost' metód môže byt' impulzom, resp. motiváciou k jeho d'alšej učebnej činnosti.

Aktivizujúcimi metódami na hodinách čítania a písania v 1. ročníku, a to hlavne v predšlabikárovom a šlabikárovom období je dôležité u žiakov stimulovat':

- jemnú motoriku a grafomotoriku (k utváraniu správnych pisatel'ských návykov), oromotoriku (k zdokonal'ovaniu správnej výslovnosti, dýchania, tvorbe foném),

- zrakové vnímanie a sluchové vnímanie (k rozvíjaniu fonematického a fonologického uvedomovania),

- priestorovú orientáciu (orientácia na ploche, v texte pri čítaní a písaní),

- vnímanie vlastného tela v priestore (čítanie, listovanie, telo pri procese písania),

- funkcie intermodality a seriality (uvedomovanie si súvislostí a postupnost' $\mathrm{v}$ procese čítania a písania).

Z uvedených oblastí je zrejmé, že proces nadobúdania elementárnej gramotnosti nie je statická záležitost', a ak má byt' dynamický a efektívny, jednou z podmienok je zoznamovat' žiakov s písanou rečou súčasne v laviciach, ale aj $\mathrm{s}$ funkčným využívaním priestoru a pohybu $\mathrm{v}$ ňom. Jedným $\mathrm{z}$ takýchto prostriedkov motivácie a zároveň stimulácie vo všetkých uvedených oblastiach môže byt' rytmika (výchova $k$ rytmu).

\section{Rytmus a miesto Orffovej školy vo vyučovaní jazyka}

Ako sme spomenuli $\mathrm{v}$ úvode štúdie, nielen odborná pedagogická prax, ale aj pedagogická veda necháva tému rytmiky $\mathrm{v}$ pedagogike na periférii. Mená predstavitel'ov rytmiky rezonujú skôr $\mathrm{v}$ pedagogickej praxi telesnej a hudobnej výchovy. Musíme spomenút' Ernsta Meumanna (1862 - 1915), ktorý ako prvý zdôraznil význam výchovy $k$ rytmu vo vzdelávaní. Vel'ký posun nastal však až v 30. rokoch 20. storočia, kedy Emil Jacquese Dalcroze (1865 - 1950) hl'adal inovatívne postupy $\mathrm{v}$ hudobnej pedagogike a dospel k názoru, že hudba a rytmus stojí nad pohybom. Čiastočne sa od jeho názorov odkláňal Rudolf Laban (1879 - 1958), ktorý za základnú zložku v rytmike nepovažoval hudbu, ale slovo a pohyb. Z uvedeného môžeme tvrdit', že rytmika úzko súvisí s hudbou, pohybom a slovom. Vidíme teda opodstatnenie $\mathrm{v}$ tom, aby sme ju integrovali aj do jazykovej, resp. elementárnej 
gramotnosti. V súvislosti s výchovou k rytmu nemožno nespomenút' pokračovatel'a E. J. Dalcroza, a to Carla Orffa (1895 - 1982), ktorý svojou hudobno-rytmickou školou (metodikou) postavenou na princípe hry a improvizácie významne podporil pedagogické ciele. Dovolíme si tvrdit', že jeho metodika by mala mat' svoje miesto pri práci so Šlabikárom (hrou na otázku a odpoved' môžeme zistit' kontext vety; melodicko-rytmické hry s akcentom na zdrobneniny (pes - psíček), opozitá - ich rytmizovanie a uvedomovanie rozdielu kvantity slabik a dížky slov, zmena významu; melódia alebo dynamika slov (zlý, dobrý); práca so slovným prízvukom a dôrazom vo vete a pod.). Za hodnotné $\mathrm{v}$ tejto metodike treba pokladat' to, že žiak pri takýchto cvičeniach sa nemusí sústredit' len na synchronizáciu oka - ruky, alebo len na koordináciu oromotoriky, ale zapájame súčasne jeho celý psychofyzický aparát. Do pozornosti treba dat' aj to, že systematické zarad'ovanie rytmických cvičení podporené pohybom a hudbou môžu výrazne vplývat' na psychofyzické uvol'nenie. Naše tvrdenia podporíme aj výsledkami výskumu, ktorý v minulosti realizovali (Rupiper, Thesis, 1950: 49) na Katedra psychológie Univerzity v Južnej Dakote v USA, kde sa ukázalo, že hudobné činnosti - hudobno-pohybové, percepčné, inštrumentálne, spevácke, s dôrazom na rytmus skladby pomohol diet'at’u výrazne v motorickej oblasti. Rovnako sa ukázalo, že postupne jeho nekoordinované pohyby, ktoré boli v úvodnej fáze spôsobené vnútorným napätím, sa postupne javili byt' zrelaxovanejšie a ladnejšie.

Musíme konštatovat' že koncom 20. storočia v našich školách stála rytmická výchova skôr v úzadí aj v telesnej výchove, a dôraz sa kládol nie na kultúru pohybu, ako životnú hodnotu, ale skôr na telesnú zdatnost'. Len pripomenieme, že na jej vážnost' už dávnejšie apelovala Eliška Blahova (1949), významná reformátorka výchovy k rytmu.

\subsection{Hry so slovom, rytmom a rýmom - princíp napätia, uvol'nenia a zážitku}

Vyššie sme priblížili tvorivú dramatiku ako sociálno-estetické učenie, ktoré v sebe zahŕn̆a aj oblast' rytmu a rytmiky. Rytmus je skôr estetickou kategóriou, ktorá však zohráva v sociálnej oblasti človeka dôležitú rolu (chôdza, dýchanie, hovorenie). V hovorenom alebo písomnom prejave (pri písaní písaného písma) môžeme hovorit' o pravidelnosti usporiadania grafém - jazykového kódu. Pre rytmus je príznačný istý prúd, tok, súmernost', súlad, systematickost', harmónia, ladnost', čo nám dodáva istotu a navodzuje uvol'nenie. Podobne, ako je to so striedaním dňa a noci, prílivu a odlivu, striedanie štyroch ročných období, tlkot srdca, alebo pravidelnost' dýchania. Ak však túto pravidelnost' niečo, niekto naruší, nastáva napätie, neistota a hl'adanie východiska. Práve na striedaní napätia a uvol'nenia, teda na kontraste by sme mali štruktúrovat' aj vyučovanie. Okrem iného to môže pomôct' aj učitel'ovi zvýšit' koncentráciu žiakov na vyučovaní.

Obsah elementárnej gramotnosti je v 1. ročníku základnej školy prioritne reprezentovaný predmetmi čítanie a písanie s časovou dotáciou 9 hodín týždenne. Postupne sa s písanou rečou žiak kontaktuje aj na hodinách matematiky, prvouky a pod. Je preto dôležité, aby učitel', tak ako zdôrazňoval aj Goodman (1986, In Zapotocna, Petrova, 2010), integroval jazykové vyučovanie a doplníme, že by mal vo vel'kej miere k motivácii o písanú reč využivat' aktivizujúce metódy. To všetko by sa malo uskutočňovat' v priaznivej atmosfére a celkovej klíme triedy, aby žiak chcel vstupovat' aktívne do učebnej činnosti, a to bez strachu, že sa pomýli, neuspeje. Jeho aktívny prístup vo vyučovaní môže učitel' determinovat' svojou didaktickopedagogickou koncepciu, výberom motivačno-aktivizujúcich metód založených na princípoch hrovej činnosti. Ak vychádzame z vnímania hry, z jej filozofického hl'adiska ako dobrovol'nej a spontánnej činnosti človeka (bližšie Huizinga, 1971), ktorá by mala mat' atribúty - napätie (očakávanie) - uvol’nenie - zážitok, môžeme očakávat', že nadobúdanie elementárnej gramotnosti potom môže prerást' do vnútornej motivácie žiaka a záujem o písanú reč. 
Nemožno opomenút' fakt, že hra je spojená s emóciami a zážitkom, jej proces a výsledok má teda značný vplyv na uchovávanie a dlhodobé zapamätanie. V súvislosti s vyučovacím procesom o týchto aspektoch pojednáva neuropedagogika a neurodidaktika. Ide o novú, pre súčasné storočie aktuálnu interdisciplinárnu oblast', ktorá sa zaoberá procesom učenia sa a vyučovania s dôrazom na poznatky z neurovedy. Pojem neurodidaktika, ako to uvádza Petlák (In Petlak, Valabik, Zajacova, 2009: 12) prvýkrát použil vo svojich prácach G. Preiss v roku 1992. Neurodidaktiku charakterzoval Preiss tak, že „vychádza z učebných schopností l'udí a hl'adá podmienky, od ktorých sa odvíja najlepšie učenie, pričom nosnou myšlienkou bolo presvedčenie že plasticita mozgu a učenia sú v jeden celok vytvárajúci vzájomný vzt'ah". Neurodidaktika sa teda viaže k vyučovaniu a učeniu sa žiakov. Pre učitel'a to znamená aj to, že by sme mali vo vyučovaní postupovat' vo výbere metód s rešpektom k učebným štýlom žiakov. Neudodidaktika tiež zdôrazňuje, že málo podnetné prostredie učenie obmedzuje, a naopak, čím viac je zapojených viacej zmyslov súčasne s pohybom, tým viacej posilnení - upevnení a „spojení“ prebieha v mozgu. Takýmito aktivizujúcimi metódami vo vyučovaní môžu byt' aj hry a cvičenia založené na rytme.

V jazykovej gramotnosti výchova k rytmu je vo vzájomnom vzt'ahu s rýmom. Je viacero dôkazov o tom, že rým a rytmus sú oddávna späté s hovoreným slovom. Dôkazom toho sú jednoduché útvary detskej l’udovej slovesnosti, príslovia, porekadlá. Mnohí autori sa týmto fenoménom nechali inšpirovat' a neskôr vznikali tzv. detské abecedáre, o ktorých môžeme hovorit', že mali istý didaktický zámer. Ten viedol k zvládnutiu techniky čítania, pričom sa u diet'at’a podnecovalo fonematické a fonologické uvedomovanie. Treba pripomenút', že ak je slovný prejav uvol’nený, ale zároveň dôsledný, je rytmický. Podobne, aj detské rečňovanky, hádanky pôsobia hravo a uvol'ňujúco, ked' je prítomný rytmus a rým. F. Straus (2007, s. 206) v Slovniku poetiky definuje rým ako „zvukovú zhodu hlások (samohlások, spoluhlások) na konci slova, alebo skupín slov na konci veršov, polveršov alebo syntaktických úsekov v tej istej slohe básne“. Ked’že o rýme nehovoríme ako o izolovanom segmente - hláske, slabike, ale o verši, slove, syntagme, teda o akomsi kompozičnom prvku, je to dôkaz toho, že tento prvok je spätý s rytmom. Rytmus nám ul'ahčuje nachádzat' zvukové zhody. Rytmický impulz považuje Straus F. (2007: 227) za očakávanie, kde vidíme zhodu, ako sme to uviedli aj vyššie, s impulzom k hre. Ide teda o akúsi hru, ktorú sprevádza l'ahkost' v procese tvorby s akcentom na tvorivost'. Toto naše tvrdenie podporíme Kopalom (1995: 97), ktorý píše, že „rým má byt' bohatý a nenásilný, tak, aby verš ním končiaci uspokojoval ucho ako harmonická hudba končiaca dokonalým súzvukom“. Naša pedagogická prax ukazuje, že ak žiaci nachádzajú vlastnou expresívnou tvorbou zvukové zhody rýmových dvojíc, prináša im to pozitívne emócie (radost' z úspechu). V mnohých prípadoch sú o to silnejšie, ak tento proces sprevádza pohyb (jeden pohyb - tlieskanie, alebo ak je rýmový segment dlhší, súbor pohybov podl'a slabík - tlieskanie, dupnutie, otočenie a pod.). V súlade $\mathrm{s}$ teóriou neurodidaktiky ide o náročný pohyb, kedy u žiaka dochádza k prepojeniu viacerých mozgových štruktúr (vnímanie, pozornost', myslenie, reč v súčinnosti s oromotorikou, hrubou motorikou, priestorovou orientáciou), čo vplýva teda na priestorovú, resp. aj dlhodobú pamät'.

\subsection{Niektoré skúsenosti z pedagogickej praxe a odporúčania}

V praxi sa nám osvedčilo to, aby žiaci po nachádzaní nových slov rýmovaním a rytmicko-pohybovým vyjadrením dokázali aj pohybom alebo pantomímou - hrou $\mathrm{v}$ role - vyjadrit' význam slov, ktoré tvoria. Tým sa nám darí u žiakov rozvíjat' nielen sústredit' sa na zvukovú zhodu slov, ale uvedomit' si, že zvuková zhoda a dížka slov nie sú zákonite $\mathrm{v}$ zhode $\mathrm{s}$ významovou rovinou slova. Takéto postupy prinášajú žiakom kognitívne, psychomotorické, ale aj sociálno-emocionálne podnety pre rozvoj 
ich osobnosti. Môžeme uvažovat' aj o tom, že uvedené didaktické postupy môžu byt' prospešné aj pre žiakov s narušenou komunikačnou schopnost'ou, prípadne pre elimináciu žiackych komunikačných neúspechov, resp. pre akceptáciu diverzity (bližšie Polakovicova, 2015, Babulicova, 2016). Dovolíme si tvrdit', že aj v takomto procese môžeme hl'adat' začiatky záujmu o čítanie, resp. zvyšovanie kvality ich čitatel'skej gramotnosti žiakov. Používanie jazykového kódu v 1. ročníku ZŠ by malo byt' rozhodne podporené pohybom, najlepšie hrou v role. Hra v role je základnou metódou už spomínanej tvorivej dramatiky. Ak by sme vychádzali z filozofie hry, jej korene možno hl'adat' v hrách typu mimikry, čo znamená akoby únik do fiktívneho sveta, alebo ak sa pozrieme na túto hru - prirodzenú detskú činnost' z pohl'adu pedagogiky, ide o námetové hry. Je dôležité si uvedomit', že vel'kou devízou pre učitel'a je to, že ide o metódu (jazyk diet'at'a/žiaka), ktorej rozumie každé diet'a tejto vekovej kategórie, tak je na zváženie, či nemá význam na nej stavat'. Prostredníctvom pohybového vyjadrenia - hry v role učitel'ka môže zistit', či žiak danému pojmu, pokynu, kontextu rozumie. To však už nie je predmetom tejto štúdie (bližšie Kollárová, 2013a).

Naša pedagogická prax ukazuje, že žiaci vedení takýmto systematickým prístupom, ktorý je založený na hre s rytmom a rýmom, sú odvážnejší v hlaadaní metafor a d'alších básnických figúr, ktoré im neskôr pomáhajú k tomu, aby s jazykom narábali pružnejšie a s istotou. Rytmikou tiež môžeme rozvíjat' u žiaka tieto oblasti:

- rytmické cítenie (pohybom aj rečou pri narábaní s jazykovým kódom),

- reč a rečové ústrojenstvo (dýchanie a fonácia - tvorba foném a hlasu; artikulácia a zmysel pre rytmus v slove a slov - striedanie prízvučných a neprízvučných slabík, rytmus veršov, slovného prejavu, pravidelnost' prerážania artikulačného výdychového prúdu),

- synchronizáciu hemisfér (súčasne je zapojených viacero kognitívnych a psychomotorických funkcií; synchronizácia oka a ruky pri písaní; zrakové, sluchové, hmatové podnety preniest' do oromotoriky, grafomotoriky, do priestoru a pod.),

- uvol'nenie, psychofyzického napätie (zbavit' sa strachu pri nadobúdaní elementárnej gramotnosti, v komunikačnom prejave, pocítit' úspech z vlastnej tvorivej aktivity),

- zmysel pre prácu so slovom a pohybom (pohybom, pantomímou - hrou v role môže žiak vyjadrit', ako slovu, slovnému spojeniu rozumie, ako ho žiak pretransponuje do sociálneho kontextu),

- prebudit' u žiakov záujem o pohybové aktivity (môžu na nich stavat' ich d'alšie športové činnosti podl'a ich záujmov, nebát' sa experimentovat' so slovom v súčinnosti s pohybom - pantomíma),

- orientáciu v priestore a skupinovú citlivost' (pohybové vyjadrenie významu slova, uvedomit' si, ako funguje telo v priestore - rad, kruh, zástup, naháňačka a pod., ako aj rešpektovat' partnera priestore),

- poriadok, preciznost', presnost' a vôl'u (rytmus znamená pravidelnost', vnesenie poriadku, v čitatel'ských a ortografických zručnostiach zlepšovat' svoj prejav),

- motivácia $\boldsymbol{k}$ učeniu (stimulácia pozitívnych emócií - tešit' sa z objavovania jazykových súvislostí čítanej a písanej reči, túžba a záujem podiel'at' sa na vlastnej expresívnej tvorbe),

- schopnost' improvizovat' a nebát' sa experimentovat' so slovom (hl'adat' a objavovat', porovnávat' a prirad'ovat' nové slovné spojenia, vymýšs'at' situácie, v akých prečítaná veta mohla byt' vyslovená a pod.).

Tieto naše postrehy potvrdzujú aj výsledky zahraničných štúdií (McDonald, Simons, 1989: 100) kde autori zdôraznili dôležitost' výučby v súčinnosti s motorickými návykmi počas tohto vekového obdobia. Pripomínajú tiež výučbu 
piesní v prepojení s hudobno-pohybovou zložkou, rozmanitými kruhovými hrami, pre ktoré je príznačný priestor, pretože sa ukázalo, že dokážu na nich v budúcnosti stavat'. Tiež ich následne „kreatívne“ dokážu využívat' počas celého života na vyjadrenie slova, pohybu, hudby. Môžeme konštatovat', že podobne je to aj v jazykovej oblasti, takýmto prístupom u žiakov utvárame a stimulujeme aj modulačné faktory reči, ktoré následne v sociálnej komunikácii dokážu funkčne využívat'.

Ako upozornil Moog (1976: 43-48, In McDonald, Simons, 1989) rytmické pohyby deti iniciujú medzi 5. - 8. mesiacom. Aj ked' ešte $v$ tomto období deti nedokážu udržat' pravidelný rytmus. Logicky vyplýva, že tieto schopnosti sa zvyšujú vekom a skúsenost'ami. Aj preto sme presvedčení, že treba v detoch stimulovat', rozvíjat', resp. stavat' na tom, čo v nich prirodzene je. Len pripomenieme, že v žiadnom prípade sa pri takýchto činnostiach nemôžeme zamerat' na výsledný efekt, ale kl'účovou je pre diet'a/žiaka skúsenost's týmto tvorivým procesom.

Uvedieme ešte princípy, ktoré sa nám osvedčili pri uplatňovaní rytmiky $\mathrm{v}$ procese nadobúdania elementárnej gramotnosti. Ide o zarad'ovanie:

- rytmických cvičení (hra s rýmom a rytmom v slovách - slabikovanie a porovnávanie napr. formy, kvantity; dynamika, tempo, forma, výraz slova - dešifrované, resp. prečítané slovo pretransponovat' do významového kontextu komunikačných situácií);

- priestorových cvičení (aby pochopili žiaci priestorovú orientáciu a ortografické záležitosti čítania a písania na ploche, je dôležité si ich prežit' $\mathrm{v}$ reálnom priestore - hry na zmeny smeru, tvaru, pohybu a priestorových dráh);

- hudobných hier (odporúčame zarad'ovat' hudobno-pohybové hry, permanentnú prácu sútvarmi detského slovesného folklóru - vyčítanky, riekanky a i. - s využitím melodizácie a rytmizácie; aj v šlabikárovom období pri vyvodzovaní foném a grafém využívat' l'ahkoovládatel'né rytmické nástroje - zvukový diktát, slabikové hádanky a pod.);

- verbálny faktor (neopakovat' po učitel'ke prečítané slová, ale slovnou motiváciou naviest’ žiaka k tomu, aby vycítil a porozumel, v akej situácii by bolo slovo, veta použitá),

- rôznorodost' (ked'že rytmické cvičenia sú na báze hry, žiak očakáva, d’alšie varianty, ktoré budú obsahovat' prvok napätia, aby sa žiak opät' so záujmom chcel do hry - učebného procesu vrátit'. Práca so Šlabikárom musí byt' rozmanitá a pre žiaka inšpiratívna, aby ho chcel otvorit' aj v domácej príprave.),

- uvol'nenie - napätie (z hl'adiska udržania pozornosti je dôležité štruktúrovat' edukačné aktivity tak, aby sme žiakov viedli k uvedomelému napätiu a uvol'neniu, zároveň tieto aktivity by mali byt' vystavané na princípe kontrastu),

- hudobný sprievod (vo vel'kej miere zarad'ovat' zvukové hry, resp. tvorivé zvukové diktáty, zvukové príbehy - napr. zvukový príbeh z predmetov v miestnosti, alebo s využitím Orffovho inštrumentáru, čím rozvíjame u žiakov produktívne jazykové komponenty - hovorenie, písanie).

Udržiavanie uvedených princípov môže viest' k reči živej, presnej, zrozumitel'nej, kultivovanej. Pri takejto práci si musíme uvedomit', že rytmika vytvára aj možnost' pre budovanie modulačných faktorov reči pre neskorší vek. Podmienkou však je, že bude zarad'ovaná systematicky. A platí, čo napísala už Stembergova (1994), že ak žiaka naučíme a zvykne si na čítanie a hovorenie rytmické, začne pocit'ovat' každú hlásku ako záväznú súčast' reči. 
3 Výskumné zistenia $z$ uplatňovania rytmických cvičení v procese nadobúdania elementárnej gramotnosti v 1. ročníku základnej školy

$\mathrm{V}$ rámci riešenej problematiky sme uskutočnili $\mathrm{v}$ pedagogickom teréne za posledné tri roky viaceré výskumy, ktorých výsledky singnalizujú, že má význam sa venovat' v pregraduálnej príprave učitel’ov predprimárneho a primárneho vzdelávania ako aj v rámci kontinuálneho vzdelávania pedagogických pracovníkov dôslednejšej a hlavne komplexnejšej príprave z oblasti aktivizujúcich metód na vyučovaní, do ktorých integrujeme poznatky a skúsenosti z viacerých vyučovacích predmetov. V 1. ročníku základnej školy pri nadobúdaní elementárnej gramotnosti by to malo byt' prevažne z oblasti výchovných predmetov, pretože nielenže je žiak konfrontovaný denne s úlohami na jeho kognitívny rozvoj, ale navyše vstupuje do prostredia, ktorý mu je neznámy, rovnako ako priestor, v ktorom sa musí zorientovat'. Táto neistota podmieňuje jeho rozprávanie či nadväzovanie kontaktov, možno aj počúvanie, pretože je príliš ponorený do seba. Prvým krokom by malo byt' zo strany učitel'a pracovat' na vzt'ahu, zakladat' ho na dôvere, akceptácii a úprimnosti. Tento vzt'ah s prvákmi nemožno budovat' len na princípe hovorenie (učitel') - počúvanie (žiak), ale cez všetky didaktické postupy učitel'a a komunikačné príležitosti žiaka v nich.

$\mathrm{V}$ nasledujúcej časti predstavíme niektoré výsledky $\mathrm{z}$ uskutočneného výskumu v školskom roku 2015/2016, kde sme experimentálnym overovaním v 1. ročníku základnej školy zistovali, do akej miery môžu mat aktivizujúce metódy založené na rytmickej hre vplyv pri nadobúdaní elementárnej gramotnosti. V aktivizujúcich metódach je akcent kladený na činnost' žiaka a učitel' v nich vystupuje skôr ako facilitátor. V procese skúmania sme dôsledne dbali na ich pravidelné a systematické zarad'ovanie. Išlo o metódy typu rolových hier, hry na rytmickú prácu so slovom, s písmom, pohybom, hudobnými činnost’ami. Bolo to výhradne na hodinách čítania a písania, pričom sa rešpektovalo to, aby vyučovanie bolo v súlade s učebnicou Šlabikár. Sústredili sme sa na všetky štyri komponenty jazykovej gramotnosti (počúvanie, hovorenie, čítanie, písanie). Výskum sme uskutočnili kvalitatívno-kvantitatívnou metodológiou. Jeho kauzálnym problémom bolo: Vplyv aktivizujúcich metód na rozvoj elementárnej gramotnosti na hodine materinského jazyka užiakov prvého ročníka základnej školy. Vychádzajúc z uvedeného problému bolo následným ciel'om overit' a zistit', do akej miery môžu tieto aktivizujúce metódy založené na rytme a rytmike vplývat' na úspešnost' žiakov pri nadobúdaní elementárnej gramotnosti. Treba povedat', že táto úspešnost' v podobe kvalitatívnych zmien nás zaujímala vo všetkých štyroch oblastiach gramotnosti. Nezávislou premennou bolo uplatňovanie didaktických metód a závislou premennou bola úroveň rozvoja elementárnej gramotnosti. Na základe teoretických východísk, ktoré sme popísali v predchádzajúcich kapitolách, do tohto pedagogického výskumu sme vstupovali s hypotézou: Ak využijeme aktivizujúce metódy s dôrazom na rytmiku vo vyučovani materinského jazyka, tak experimentálna skupina dosiahne lepšie výsledky v testovaní, než kontrolná skupina. K experimentu sme potrebovali teda experimentálnu a kontrolnú skupinu. Ked’že akékol'vek zásahy do vyučovacieho procesu sa odvíjajú od individuálnej koncepcie učitel'a, vybrali a overili sme kvalitatívnym nástrojom dvoch participantov (učitel'ov), resp. štyroch participantov (rodičov), s ktorými sme uskutočnili interview, aby sme si komparáciou získaných dát overili, či skutočne vo svojej pedagogickej praxi učitel' uplatňuje aktivizujúce, resp. tradičné metódy. Ked’že v kvalitatívne ladenom výskume musí pri výbere výskumného súboru participantov niečo spájat', výber rodičov bol podmienený tým, že už mali v predchádzajúcom období prváka, ktorého vybraný participant učil, tak vedeli posúdit', aké vyučovacie postupy učitel' uplatňuje. Následne sme pristúpili k výberu výskumných subjektov, ktorými boli žiaci tried vybraných predchádzajúcich participantov. Týmto nám vznikli dva vybrané subjekty - experimentálny subjekt (d’alej ES, kde sme uskutočňovali experimentálne zásahy v podobe pravidelného 
začleňovania didaktických metód založených na aktivite žiakov s akcentom na rytmiku, a to štyri úvodné mesiace $\mathrm{v}$ školského roka) a kontrolný subjekt (d'alej len KS, kde sme postupovali tradičnými vyučovacími postupmi, teda vyučovaním prevažne počúvaním a reagovaním žiaka $\mathrm{v}$ sede $\mathrm{v}$ laviciach). Treba upozornit', že po uskutočnení úvodného testovania sme museli pristúpit' $\mathrm{k}$ takému kroku, že sme z uvedených subjektov vybrali len po 6 participantov, ktorí mali zhodné výsledky testovania vo všetkých štyroch oblastiach (hovorení, počúvaní, čítaní, písaní). Pripomenieme, že $\mathrm{v}$ experimente plnenie podmienok kontroluje experimentátor, $\mathrm{v}$ našom prípade sme boli dve (Kmetova, Kollarova, 2016), ktoré sme nielen kontrolovali, ale aj konzultovali experimentálne zásahy, navrhovali aktivity na d’alší týždeň, konzultovali vyučovanie aj v kontrolnom subjekte). Ako sme už spomenuli, obidve skupiny absolvovali vstupný pretest. Všetky aktivity vyplývajúce z výskumného nástroja boli primerané s dôrazom na vekové osobitosti, na vzdelávací program ISCED 0 a ISCED 1 a mali všetky atribúty hry a aktivizujúcich metód. $\mathrm{V}$ podobnom duchu sme realizovali aj výstupné testovanie - posttest, pričom úlohy boli náročnejšie, s rešpektom na plnenie časovo-tematických plánov a výkonových štandardov. Zdôrazníme, že v týchto výskumných nástrojoch (pretest, posttest) sme sa nesústredili na rytmické cvičenia, rytmika nám slúžila skôr ako prostriedok v procese skúmania. Celé výskumné obdobie bolo podporené neštruktúrovaným pozorovaním. Pripomenieme, že obidva subjekty postupovali podla toho istého Šlabikára. Pri experimentálnych zásahoch sme vychádzali vždy z obsahových a výkonových štandardov ISCED 1. Zásadnou podmienkou v ES bolo, aby bolo vyučovanie ladené aktivizujúco a s dôrazom na využívaniu rytmických hier - využívanie priestoru, hudobno-pohybových aktivít, hru na telo, rytmické cvičenia so slovom a veršom, práca $\mathrm{s}$ rýmom, rytmické cvičenia $\mathrm{v}$ grafomotorike - a aby celé vyučovanie bolo pre participantov prít’ažlivé aktivitami, ktoré by mali byt' nasmerované na záujem a vnútornú motiváciu žiakov. Po 4-mesiacoch, kedy ešte stále boli participanti v šlabikárovom období pri vyvodzovaní foném a grafém, sme uskutočnili testovanie. Naše didaktické testy, ktoré vychádzali z pretestov sme znáročnili kvôli tomu, že žiaci už ovládali niektoré fonémy a grafémy v abecede, čiastočne vedeli čítat' a písat', resp. rešpektovali sme ich kognitívne, teda aj celkové psychomotorické napredovanie. Finálne testovanie bolo realizované v rovnakých podmienkach pre paticipantov, ako pretest.

Všetky uskutočnené interview sme prepísali do protokolov a následne ich otvorených kódovaním vyhodnocovali, podobne sme takto zaznamenali aj pozorovania. Z dôvodu limitovaného rozsahu chceme $\mathrm{v}$ tejto štúdii predstavit' skôr kvantitatívne výsledné dáta. Priblížime, o úlohy akého typu v testovaní išlo a zároveň predstavíme výsledky.

Počúvanie - boli to úlohy typu: nájst'v slovách spoločnú hlásku na začiatku slova a na konci slova, z radu slov vylúcit' to slovo, ktoré nemá rovnakú hlásku, na základe počutých slov vybrat' zo súboru obrázky.

Pri vstupnom testovaní bol rozdiel $0,93 \%$, konkrétne experimentálny subjekt (ES) dosiahol 72,22\% a kontrolný subjekt (KS) dosiahol 71,29\% úspešnost'. Vo finálnom testovaní boli tieto rozdiely výraznejšie, a to ES sa zlepšil o 20,37\% (dosiahol na konci úspešnost' 92,59\%) a KS si polepšil hodnotenie o 12,4\% (dosiahol teda $83,33 \%$ úspešnost').

Pri oblasti počúvanie si dovolíme konštatovat', že vyučovania založeného na vlastnej aktivite žiakov, ktorá je podporená pohybom, priestorovými cvičeniami, s dôrazom vlastnú aktivitu nemusíme mat obavy $\mathrm{z}$ nepozornosti žiakov a ich koncentráciou iných počúvat'. Potvrdil nám to aj celoslovenský výskum (Kollárová, 2010) z oblasti uplatňovania metód tvorivej dramatiky v primárnom vzdelávaní. Zároveň je to $\mathrm{v}$ súlade $\mathrm{s}$ teoretickými východiskami, kde sme uviedli závery autorov, ktorí apelovali, že žiak by mal byt' na vyučovaní uvol'nený a rovnako v tomto veku 
potrebuje aj pohybovú aktivitu a príležitost' pre spätnú väzbu a zážitok sprevádzaný pozitívnymi emóciami z vlastného úspechu. Z kódovania pozorovaní bolo tiež zaujímavým zistením, že žiaci sú odvážnejší v komunikácii a prichádzajú z vlastnými návrhmi aktivít.

Hovorenie - úlohou bolo napríklad: rozprávat čo si všimli cestou zo školy (hodnotila sa slovná zásoba, syntagmy, štylistika), tvorili vety z daných slov, zorad'ovali obrázky podl'a deja a následne porozprávali pribeh.

$\mathrm{V}$ tejto oblasti bol medzi subjektami na začiatku rozdiel 2,22\%, pričom ES mal v preteste $52,22 \%$ a KS dosiahol 54,44\%. V zložke hovorenie sa vo finálnej fáze tiež darilo skôr ES, pretože sa zlepšili o 27,78\%, teda skončili na 80,00\%-tách úspešnosti. KS sa samozrejme tiež zlepšil, a to o $12,23 \%$. Celkovo to teda bolo na $66,67 \%$, treba si však všimnút', že pri vstupnom testovaní bol KS úspešnejší.

Z uvedených výsledkov zlepšenia ES o $27,78 \%$ a KS o $12,23 \%$, ako aj z výsledkov záverečného testovania a pozorovania si dovolíme tvrdit', že vel'kú úlohu pri hovorení participantov zohráva neuvol'nenie sa pri prevažnom sedení v laviciach a zároveň minimálny priestor pre komunikačnú skúsenost' žiaka, resp. ktorá je mimo rámca učebnice. Toto nám otvára možnosti d'alšieho skúmania osobitostí komunikácie na vyučovaní materinského jazyka v 1. ročníku ZŠ.

Čítanie - participanti mali úlohy typu vyriešit' čitankové rébusy; priradit' a prečitat' k obrázkom slová, pričom boli vynechané písmená; prečitat mal'ované čitanie.

V tejto oblasti bol ten rozdiel v úvodnej fáze väčší o 5,00\%, pretože ES sa podarilo uspiet' v testovaní na $51,66 \%$ a KS na 56,66\%. Všimnime si, že opät' je úspešnejšia práve $\mathrm{KS}$, aj ked' musíme konštatovat', že v testovaní vyšli obidva subjekty skôr podpriemerne. Vo finále sa v čítaní však ES zlepšila o 38,34\%, teda subjekt bol úspešný na $90,00 \%$. KS si tiež zlepšila svoje výsledky, a to na $77,78 \%$, čo je o $21,12 \%$ viac než v úvodnom testovaní.

Prioritne sa v 1. ročníku v školách kladie dôraz na čítanie a písanie žiakov. Výsledky ukazujú, že uvedené didaktické postupy založené na aktivite žiaka, rytmike, pohybe a hudobných činnostiach, uplatňované na hodinách materinského jazyka v šlabikárovom období, môžu byt' pre žiaka, učitel'a, rodiča vo vel'kej miere prínosné. Môžeme uvažovat' o tom, že na týchto overených postupoch by sme mohli stavat' aj pri rozvíjaní čitatel'skej gramotnosti. Sme presvedčení, že toto je pre ňu to zlomové obdobie, a to nemáme na mysli len techniku čítania, ale aj zážitok z čítania, ktorý vyvolá záujem o čítanie.

Písanie - v tejto oblasti mali participanti (najskôr) prstom napisat' tri tlačené písmená, vytvorit' pomocou prstov rúk tlačené písmeno, vytvorit' telom pismeno, čast' písaného tvaru grafémy napisat' na linajku.

V poslednej zložky gramotnosti bola v štarte výskumu percentuálna úspešnost' ES a KS zhodná, a to 59,33\%. Napriek tomu, že vychádzali z rovnakej pozície, v závere bol ES úspešný na $88,00 \%$, zlepšil sa teda o $28,67 \%$ a KS sa zlepšil o $22,67 \%$, na $82,00 \%$.

Proces písania je pre žiaka prvého ročníka náročnejší než čítanie, resp. než všetky ostatné zložky gramotnosti. Vidíme však, že obidva subjekty sa v tejto oblasti výrazne posunuli $\mathrm{k}$ lepšiemu. Písanie vyžaduje od žiaka väčšiu koncentráciu pozornosti a navyše ho pohybovo zväzuje. Z výsledkov však môžeme vyčítat', že ked' dáme žiakom príležitost' v časti hodiny čítania na rozličné aktivity v priestore, neplatí, že tým utrpí kvalita pisatel'ských zručností žiakov.

\subsection{Zo záverov výskumu}

Sumár záverečných výskumných ukázal, ES sa zlepšil v oblastiach podl’a poradia: 1. čitanie, 2. písanie, 3. hovorenie, 4. počúvanie, čo je priemerne za každú oblast' $28,79 \%$ a KS sa zlepšil najviac v: 1. písaní, 2. čítaní, 3. počúvaní a 4. hovoreni, čo je 
v priemere za každú oblast' 17,10\%. Môžeme konštatovat', že hypotéza, s ktorou sme vstupovali do tohto výskumu inšpirovaní teoretickými východiskami uvedenými v predchádzajúcich subkapitolách, sa nám potvrdila, a to vo všetkých štyroch sledovaných oblastiach gramotnosti. Uvedený výskum nám signalizuje to, že má význam venovat' pozornost' nielen v školskej praxi, ale hlavne vo výskumnej oblasti aj takej problematike, akou je rytmika - výchova k rytmu. Ukazuje sa, že ide o fenomén, ktorý vo vyučovaní podmieňuje nielen naše emocionálne kvality, ale zároveň aj psychomotriku a kognitívne funkcie. Vieme, že motorika a psychika vel'mi úzko spolu súvisia a motoriku je vhodné rozvíjat' psychomotorickými hrami, v ktorých je aktívne zapojené vnímanie, schopnost' stabilizácie (t’ažisko rovnováhy je vo vnútornom uchu), čím rozvíjame koordinačné schopnosti, schopnost' rýchlej reakcie a pod. Pri nadobúdaní elementárnej gramotnosti je nesmierne dôležité brat' do úvahy dôsledky tejto pohybovej aktivity detí. Ťažiskom celého tohto procesu je totiž schopnost' vnimat', resp. zachytit' zmyslami grafému, alebo fonému a pretransponovat' ju do písomného, alebo zvukového kódu, a to podl'a možností čo najrýchlejšie, navyše porozumiet' významovej a kontextovej rovine. Aj $\mathrm{z}$ tohto dôvodu odporúčame zarad'ovat' systematicky aktivizujúce metódy založené na pohybovej aktivite, osobitne cvičenia na koordináciu a rovnováhu, ktorou cvičíme zároveň postreh (rýchlu reakciu na zmyslový podnet), teda aktivity zamerané na psychomotorické ciele. Rytmické hry so slovom, s pohybom, so zvukom, so slovom a melódiou súčasne, prípadne hudobnopohybové hry a hry na telo sú toho jasným príkladom. Práve v hudobno-pohybových hrách a hrách na telo, ktoré nám môžu slúžit' nielen na analýzu slov na slabiky, na porovnávanie dížky slov alebo na nachádzanie nových rýmov, ale diet’a si rozvíja nimi aj zmysel pre už spomínanú rovnováhu, stabilitu, postreh, čo je podmienkou k zvládnutiu techniky čítania a písania.

\section{Záver}

V súčasnosti rezonuje na všetkých stupňoch vzdelávania problematika čítania žiakov, konkrétne čitania s porozumením. Považujeme to za problém, ktorý treba naliehavo riešit', a sme presvedčení, že by to malo byt' práve $\mathrm{v}$ začiatkoch primárneho vzdelávania pri nadobúdaní elementárnej gramotnosti, kedy nejde len o výučbu techniky čítania. Ide o komplexný proces nadobúdania receptívnych (počúvanie, čítanie) a produktívnych (rozprávanie, písanie) komunikačných zručností, s akcentom na dešifrovanie sluchovo-fonologického a zrakovo-percepčného abecedného kódu. Aby bol tento proces úspešný, jeho základnou podmienkou je výber edukačných metód a d'alších didaktických komponentov tak, aby rešpektovali $\mathrm{v}$ plnej miere kognitívne možnosti s rešpektom na učebné štýly žiakov, na ich psychomotorické predpoklady a sociálno-emocionálnu stránku osobnosti. Rytmika - výchova k rytmu súvisí so zážitkom a uvol’nením. Okrem plynulého pravidelného pohybu sa k rytmu viaže aj zvuk. Hláska, slovo, veta je ladenie zvukov a zvuk možno považovat' za stimul pohybu. Napriek tomu, že v ňom ide o zložité kognitívne, percepčno-motorické a zároveň emocionálne procesy, mal by pedagóg vyberat' také didaktické postupy, aby žiak dostal príležitost' sám objavovat' súvislosti medzi jazykovým kódom a sociálnou realitou. Do tohto postupu sa oplatí zo strany učitel'a investovat' aj z toho dôvodu, že v takomto nadobúdaní poznatkov sú zároveň aktívne tie pamätové štruktúry priestorovej pamäte, ktoré sa viažu $\mathrm{k}$ zapamätávaniu a okamžitému vybavovaniu.

\section{Bibliographic references}

BABULICOVA, Z. 2016. Rozvoj kognitivnych funkcii deti s odlozenou povinnou skolskou dochadzkou. In Slavonic Pedagogical Studies Journal. Vol. 5, n. 1, pp. 143 161. ISSN 1339-8660. 
KOLLAROVA, D. 2002. Mimoslovna a slovna komunikacia. In M. BENESOVA D. KOLLAROVA: Tvoriva dramatika pre stredne skoly. Bratislava: SPN. pp. 42-49. ISBN 978-80-08-03307-X.

BIROVA, J. 2016. Odporucane tematicke okruhy v ucebniciach francuzskeho jazyka pouzivanych v slovenskom vzdelavacom systeme. In Slavonic Pedagogical Studies Journal. Vol. 5, n. 2, pp. 126-142. ISSN 1339-8660.

BLAHOVA, E. 1949. Pohyb, rytmus, vyraz. Prague: SU pro TV.

DUCHOVICOVA, J - PETROVA, G. 2016. Osobnostne kompetencie absolventov ako predpoklad socialnej inkluzie. In Slavonic Pedagogical Studies Journal. Vol.. 5, n. 1, pp. 184-200. ISSN 1339-8660.

FERREIRO, E. 1990. Literacy development : Psychogenesis. In GOODMAN, M. J. Ed how Children Construct literacy. Newark: IRA, pp. 12-26.

GAVORA, P. 2006. Citanie, pisanie a gramotnost - ich premeny v sucasnom svete. In Slovo o slove : Zbornik KKLV PF Presovskej univerzity. Presov: Presovska univerzita v Presove. pp. 23-30. ISBN 978-80-8068-491-X.

GOODMAN, K. 1986. What's Whole in Whole Leanguage? : A Parent/Teacher Guide to Children's Learning. Portsmouth NH : Heinemann Educational Books.

GOUGH, P. B. - JUEL, C. 1991. The first stages of work recognition. In: L. RIEBEN - C. A. PERFETTI (eds.). Learning to read. Hillsdale, NJ : Lawrence Erlbaum Asociates. pp. 3-20.

GAVORA, P. - ZAPOTOCNA, O. et. al. 2003. Modely a urovne gramotnsti. In Gramotnost : vyvin a moznosti jej didaktickeho usmernovania. Bratsilava: UKF. ISBN 978-80-223-18-69-8.

HELUS, Z. 2004. Dite v osobnostnim pojeti : Obrat k diteti jako vyzva a ukol pro ucitele i rodice. Prague: Portal. ISBN 978-80-7178-888-0.

HUZINGA, J. 1971. Homo ludens. Prague: Mlada fronta.

KMETOVA, I. (tutor KOLLAROVA, D.). 2016. Aktivizujuce metody pri nadobudani elementarnej gramotnosti. (Final thesis). Nitra: PF UKF.

KOLLAROVA, D. 2013a. Kniha ako hra : vychova detskeho citatela tvorivou dramatikou. Hlohovec: HTC media, 2013. ISBN 978-80-970833-3-5.

KOLLAROVA, D. (tutor GAVORA, P.) 2010. Vnimanie tvorivej dramatiky ucitelmi 1. stupna ZS. Bratislava: UK.

KOLLAROVA, D. 2013b. Vnimanie slabikara ziakmi 1. rocnika ZŠ. In Jazyk literatura - komunikace. Vol. 1., n. 1. 2013. pp. 1-9. ISSN 1805-689X.

KOLLAROVA, D. 2008. Vyznam hlasovej rozcvicky vo vyucovani citania v 1. rocniku ZS. In Technologia vzdelavania. Vol. 16, n. 9, pp. 11-14. ISSN 1338-1202.

KOPAL, J. 1995. Poezia pre deti (v interpretacii a recepcii). Nitra: VŠPg ISBN 8088738-97-0.

McDONALD, D. T. - SIMONS, G. M. 1989. Musical growth and development. New York: Schirmer Bookd, A Division of Mcmillan, Inc. p. 100.

PETLAK, E. 2015. O moznostiach zlepsenia pripravy buducich ucitelov. In Slavonic Pedagogical Studies Journal. Vol. 4, no. 2, p. 190-196. ISSN1339-8660.

PETLAK, E. et. al. 2008. Pedagogicko-didaktické poziadavky motivacie ziakov do ucebnej cinnosti. Nitra : UKF.

PETLAK, E. - VALABIK, D. - ZAJACOVA, J. 2009. Vyucovanie - mozog - ziak.: Uvod do problematiky mozgovokomatibilneho ucenia. Bratislava: IRIS. ISBN 97880-89256-43-3.

POLAKOVICOVA, R. 2015. Inkluzivna edukacna realita ponukajuca priestor pre akceptaciu diverzity skolskej triedy cez prizmu pedagogickej praxe. In Slavonic Pedagogical Studies Journal. Vol. 4, n. 1, pp. 2-24. ISSN 1339-8660.

PRIHODA, V. 1930. Racionalizace skolstvi. Prague: Orbis.

ROZIN, P. - GLEITMAN, L. R. 1977. The structure and acquisition of reading II : The reading process and the acquisition of the alpha betic principle. In A. REBER. - 
D. SCARBOROUGH (eds). Toward a psychology of reading. Hillsdale, NJ : Erlbaum.

RUPIPER, O. J. - THESIS, M. A. 1950. Rytmické adaptácie rozličných rytmov u detí v predškolskom veku.Vermillion : Department of Psychology in the Graduate School, University of South Dakota.

SIMONEKOVA, H. 1975. Rytmika. Bratislava: UK.

STEMBERGOVA, S. 1994. Metodika mluvni vychovy deti. Prague: STD.

STRAUS, F. 2007. Slovnik poetiky. Bratislava : Literarne informacne centrum. ISBN 978-80-89222-27-8.

VIKTOROVA, I. 2001. Zak menici se v podminkach soucasne skoly. Prague: KU. ISBN 978-80-7315-179-9.

VYGOTSKIJ, L. S. 1978. 2004. Psychologie myslení a reci. Prague: Portal. ISBN 80 717-89-4.

ZAPOTOCNA, O. 2012. Citatelska gramotnost a jej rozvoj v primarnom vzdelavani : Teoreticke vychodiska a didakticke realizacie. Bratislava: VEDA. ISBN 978-80-2241281.

ZAPOTOCNA, O. 2005. Hodnotenie ranych prejavov gramotnosti ako vychodisko diferencovaneho vyucovania citania v 1. rocniku ZS. In Pedagogicka revue. Vol. 57, n. 5. pp. 510-525. ISSN 1335-1982.

ZÁPOTOCNA, O. - PETROVA, Z. 2010. Jazykova gramotnost v predskolskom veku: Teoreticke vychodiska a namety $\mathrm{k}$ anayze a tvorbe kurikula jazykoveho vzdelavania deti v MS: Trnava : PF TU. ISBN 978-80-8082-404-4.

doc. PaedDr. Dana Kollárová, PhD.

Department of education

Faculty of education

Constantine the Philosopher University

Dražovská cesta 4, 94974 Nitra

Slovakia

dkollarova@ukf.sk 